\title{
Konstruksi realitas semu mengenai isu terorisme-radikalisme terhadap pondok pesantren
}

\author{
Kun Wazis ${ }^{1}$, Dadang Rahmat Hidayat ${ }^{2}$, Uud Wahyudin ${ }^{3}$ \\ ${ }^{1}$ Institut Agama Islam Negeri (IAIN) Jember \\ ${ }^{2,3}$, Universitas Padjadjaran, Bandung, Indonesia
}

\begin{abstract}
ABSTRAK
Kajian ini menampilkan realitas semu tentang isu terorisme dan radikalisme terhadap pondok pesantren di Indonesia yang dikonstruksikan oleh tiga media siber Jawa Pos.com, Kompas.com, dan Republika.co.id selama pemberitaan edisi online tahun 2016. Tujuan penelitian ini mengungkap praktik jurnalisme relasi kuasa media dan mendorong masyarakat melakukan gerakan kritis dalam menyikapi konstruksi realitas media yang memberitakan isu terorisme dan radikalisme terhadap pondok pesantren. Studi ini menggunakan paradigma kritis dengan analisis wacana kritis (AWK) model Norman Fairclough melalui tiga level analisis, yakni deskripsi teks berita melalui analisis bahasa kritis, interpretasi subjektif peneliti terhadap praktik wacana ketiga media siber, dan eksplanasi kritis terhadap praktik sosiokultural media. Hasil studi ini mengungkapkan tiga realitas semu. Pertama, teks berita yang dikonstruksikan mencerminkan dominasi elit dalam mewacanakan isu terorisme dan radikalisme terhadap pondok pesantren. Kedua, produksi dan konsumsi teks berita berdasarkan kebijakan redaksi media yang berorientasi kepada kepentingan pasar sehingga realitas isunya menjadi kabur (semu). Ketiga, konstruksi realitas isu terorisme dan radikalisme terhadap pondok pesantren diwarnai kepentingan ideologi media, politik media, ekonomi media, dan budaya media. Terhadap realitas semu ini, peneliti menyarankan perlunya menggerakkan literasi media melalui jurnalisme pesantren. Produk jurnalisme pesantren menjadi media perlawanan terhadap isu ini dengan menampilkan pondok pesantren sebagai lembaga pendidikan Islam rahmatan lil alamin yang menolak terorisme dan radikalisme.
\end{abstract}

Kata-kata Kunci:Realitas semu; isu terorisme-radikalisme; pondok pesantren; media siber; konstruksi realitas

\section{Pseudo-reality on terrorism-radicalism issues toward islamic boarding school on cyber media construction}

\begin{abstract}
This study presents a pseudo reality about terrorism and radicalism toward Islamic Boarding Schools which is constructed by Jawa Pos.com, Kompas.com, and Republika.co.id during 2016. Therefore, the aim of this study is to reveal the practice of journalism media power relations and encourage a critical movement in addressing media construction that preach the issue of terrorism and radicalism against the boarding school. This study employed a critical paradigm with critical discourse analysis (CDA) of Norman Fairclough model through three levels of analysis, ie, news texts description through critical language analysis, subjective interpretation of the researcher against the discourse practice of the three cyber media, and the critical explanation of the sociocultural practice of the media. The results show three false realities. First, the constructed news reflects the elite's dominance in the issue of terrorism and radicalism. Second, the production and consumption of news are based on media policy which is market oriented so the reality becomes unclear (pseudo). Third, the construction is also influenced by media ideology, media politics, media economy, and media culture. This requires media literacy through pesantren journalism. The products of pesantren journalism become the media of resistance to the issue by displaying pesantren as an Islamic education institution with rahmatan lil alamin values that rejects terrorism and radicalism.
\end{abstract}

Keywords: Pseudo reality; terrorism-radicalism issues; Islamic boarding schools; cyber media; construction of reality

Korespondensi: Dr. Kun Wazis, S.Sos., M.I.Kom. Pascasarjana IAIN Jember. Jl. Mataram No. 1 Mangli Jember Jawa Timur, Kode Pos. 68136.Email: kunwazis@gmail.com 


\section{PENDAHULUAN}

Fenomena terorisme-radikalisme yang dikaitkan dengan institusi pendidikan Islam pondok pesantren di Indonesia menjadi isu penting yang diberitakan media online. Pro kontra atas isu ini menjadi perdebatan, pertarungan, dan perebutan wacana di media online, diantaranya diberitakan Jawa Pos.com, Kompas.com, dan Republika.co.id. Fenomena isu terorisme-radikalisme yang dihubungkan dengan institusi pendidikan Islam pondok pesantren di Indonesia menjadi realitas menarik yang diberitakan media online selama lima tahun (2015-2019) (Muhibbin \& Choliq, 2019).

Hasil penelitian ini mengungkapkan sejumlah pemberitaan yang terkait dengan paham kekerasan yang dikaitkan dengan pesantren di nusantara. Di antaranya, sebagaimana diberitakan Tempo.com (2019), Ketua Umum Gerakan Suluh Kebangsaan Mahfud MD menyatakan banyaknya penganut Islam radikal di Arab Saudi yang ditangkap dan sebagian yang lolos masuk ke Indonesia. Tokohtokoh Islam radikal ini diduga datang dengan membawa uang jutaan dollar untuk mendukung gerakan radikal. Modus yang dilakukan dengan cara mendukung pesantren-pesantren tertentu atau membuat pesantren sendiri.

Sinyalemen isu terorisme-radikalisme terhadappesantrenmelaluisejumlahpemberitaan media massa online seperti Cnnindonesia.com (2018), Kompas.com (2018), dan Tribunnews (2018) melalui pernyataan Kepala Badan Intelijen Negara (BIN) Jenderal Budi Gunawan yang membenarkan adanya masjid atau rumah ibadah dan pondok pesantren yang terindikasi terpapar paham radikal (Muhibbin \& Choliq, 2019). Hal yang sama diberitakan Bbc.com (2017) dan Cnnindonesia.com (2017) yang mengaitkan terorisme-radikalisme dengan pondok pesantren di Bogor Jawa Barat, meskipun ditolak oleh pihak pondok pesantren atas stigmatisasi negatif.

Secara khusus, penulis meneliti perkembangan media online dalam memberitakan isu terorisme-radikalisme yang dihubungkan dengan keberadaan pondok pesantren di Indonesia. Hal ini dikarenakan realitas isu ini seringkali dikonstruksikan oleh media siber (cyber media) bersamaan dengan sejumlah narasi pemberitaan kekerasan tentang peristiwa aksi terorisme yang terjadi di Indonesia
(Jauhari \& Muhibbin, 2017; Widyaningrum \& Dugis, 2018).

Jawa Pos.com, Kompas.com, dan Republika.co.id merupakan media online berpengaruh yang mewakili perspektif media massa di Indonesia dalam menampilkan kontroversial realitas isu terorisme-radikalisme terhadap pondok pesantren. Kemampuan ketiga media besar ini dalam memproduksi isu dapat membangun wacana publik sesuai perspektif ideologi medianya. Produk industri berita media Jawa Pos yang dipandang merepresentasikan ideologi pasar-oplah (Hamad, 2004; Iskan, 2009), Kompas yang dipersepsikan sebagai media berideologi Kristen, dan Republika yang berafiliasi pada ideologi Islam dapat melahirkan kecurigaan publik adanya kepentingan "tersembunyi" media massa dibalik konstruksi realitas peristiwa isu tersebut sebagaimana dinarasikan dalam beragam berita (Badara, 2012).

Dugaan kepentingan media massa dibalik berita diantaranya dapat diteliti dari fakta berita online pada edisi Selasa, 02 Februari 2016. Media Jawa Pos.com, Kompas.com, maupun Republika.co.id menurunkan berita dengan sumber tunggal, yakni Kepala Badan Nasional Penanggulangan Terorisme (BNPT) Saud Usman Nasution (Dna, 2016; Indrawan, 2016; Tashandara, 2016a). Tema utama yang diangkat adalah isu terorisme-radikalisme terhadap pondok pesantren.

Peneliti memiliki alasan utama dalam melihat secara kritis konstruksi realitas ketiga berita media siber ini. Pertama, media Jawa Pos.com memuat pernyataan Saud Usman bahwa ada 19 pesantren yang terindikasi radikalisme-terorisme di Indonesia. Pesantren yang diduga itu diantaranya, Al Mukmin Ngruki Solo; Darussaadah, Boyolali, Jawa Tengah; Al Ikhlas, Lamongan, Jawa Timur; Darus Syifa di Lampung, Nurul Bayan di NTB; dan Al Muttaqin di Cirebon. Sebagian besar pondok pesantren itu dituding berkaitan dengan kelompok radikal yang pernah melakukan teror.

Pemberitaan ini menimbulkan polemik dan penolakan dari kalangan pesantren yang dituduh oleh BNPT. Diantaranya, pesantren Darusy Syahadah Boyolali, Jawa Tengah membantah isu negatif dan menyatakan bahwa masyarakat menerima pesantren mereka. Indikatornya, permintaan masyarakat akan jumlah ustadz selalu melebihi jumlah alumni, 
sekolah di sekitar pesantren meminta tenaga pengajar agama ke Darusy Syahadah, dan kegiatan dakwah yang dilaksanakan di puluhan masjid sekitar direspon baik oleh masyarakat (Mubarok, 2016).

Kedua, Kompas.com melaporkan bahwa BNPT mencatat 19 pesantren yang terindikasi radikalisme di Indonesia. Pesantren itu tersebar dari Lampung, Serang, Jakarta, Ciamis, Cilacap, Magetan, Lamongan, Solo, Nusa Tenggara Timur (NTT), Makassar, hingga Poso. Dalam menentukan nama-nama pesantren masih menemui pro kontra. Sebagian menganggap pondok pesantren itu memberikan pelajaran pada umumnya, namun sebagian menilai mengajarkan radikal. Kompas.com juga memberitakan reaksi pro-kontra kalangan elit wakil yang mempersoalkan kebenaran pernyataan pihak BNPT. Kompas.com pada edisi 04 Februari 2016 memberitakan kritik Komisi VII DPR RI, Maman Imanulhaq agar BNPT tidak terburu-buru menyimpulkan pesantren mengajarkan radikal (Tashandara, 2016).

Ketiga, media siber Republika.co.id mengonstruksikan pernyataan kepala BNPT bahwa 19 pesantren di Indonesia terindikasi mendukung kegiatan radikalisme dan terorisme. Diantara pesantren yang dicurigainya adalah Al Mukmin Ngruki di Solo, Darussaadah di Boyolali dan di sejumlah tempat lain termasuk di Ambon. Ke-19 pesantren itu ditengarai memiliki pengajar yang masuk dalam jaringan terorisme.

Terhadap tudingan pihak BNPT, media siber Republika pada edisi 04 Februari 2016, mengonstruksikan langkah Yayasan Al Mukmin yang tak tinggal diam dituduh mengajarkan radikalisme dan kantong pemasok teroris. Tuduhan semacam itu dianggap tidak proporsional dan profesional, hingga dapat menyesatkan orang banyak (Setiyoko, 2016).

Ketiga berita siber yang ditampilkan menimbulkan perdebatan publik, kontroversi, polemik, dan pertarungan wacana di ruang publik dunia maya menarik dikaji secara kritis. Salah satu sebabnya, konstruksi realitas media dipandang tidak menggambarkan wajah pesantren yang dikenal ramah dan mengajarkan Islam rahmatan lil alamin. Selain itu, pondok pesantren yang elemennya terdiri dari pondok, masjid, santri, pengajaran kitab klasik, dan kyai dikenal sebagai lembaga pengabdian diri kepada Allah, lembaga tafaqquh fi ad din (memperdalam ilmu-ilmu agama), dan lembaga pelayanan masyarakat (Dhofier, 2011; Salam, 2005). Pondok pesantren berulang kali dikaitkan dengan isu terorisme-radikalisme oleh media massa. Hal ini dapat membangun persepsi atau wacana negatif mengenai pondok pesantren yang mengajarkan agama Islam.

Dalam konteks ini, terdapat semacam "efek tumpah" (spill over effect) terhadap entitas pesantren, yakni pihak luar maupun dalam negeri yang menstigmatisasi "pesantren sebagai sarang teroris", meskipun yang dicurigai hanya belasan dari22.230 (data 2012) jumlah pesantren (kurang dari 0,001 persen) (Damanhuri, 2016).

Pada sisi yang lain, stigma negatif ini bertolak belakang dengan peran kyai sebagai aktor komunikasi yang dapat memainkan perubahan sosial dan pesantren memiliki konstribusi yang sangat besar bagi pengembangan sumber daya manusia Indonesia (Muhtadi, 2008; Suharto, 2018) dan mengajarkan Islam rahmatan lil alamin yang menolak beragam bentuk kekerasan sebagai cara untuk menyampaikan dakwah Islam di tengah-tengah masyarakat. Selama ini telah dikenal, pendidikan Islam di pondok pesantren merupakan ajaran Islam rahmatan lil alamin yang maknanya adalah Islam yang damai, santun, sejuk, dan menyejukkan (Suprayoga, 2012).

Argumentasi ilmiah untuk meneliti dengan tema ini adalah berkaitan dengan peran media dianggap penting sebab segala sesuatu yang terjadi dapat dikomunikasikan secara langsung oleh media kepada masyarakat (Lestari et al., 2018). Dalam konteks komunikasi massa yang berkembang sampai sekarang, selalu muncul dalam benak dan pikiran manusia (Syuderajat, 2017). Berita yang disusun dalam benak manusia bukan merupakan peristiwa manusia. Berita bukan peristiwa itu sendiri. Berita merupakan usaha rekonstruksi kerangka peristiwa yang terjadi.

Dalam konteks ini, posisi media massa, terutama media massa Barat seringkali memaknai Islam sebagai agama primitif yang membenarkan kekerasan atau disamakan dengan terorisme (Mulyana, 2008). Hal ini mengakibatkan stereotyping Islam sama dengan ideologi kekerasan selalu mewarnai berita-berita Barat dan belahan dunia nonBarat (Jainuri, 2016). Dalam globalisasi 
isu terorisme-radikalisme ini, media Barat menyebut pesantren telah menjadi 'breeding ground' radikalisme dan terorisme di Indonesia (Sholeh, 2007).

Pada kenyataannya, harus diakui, media massa diposisikan sebagai subyek yang mengkonstruksi realitas, lengkap dengan pandangan, bias, dan pemihakannya. Ia memiliki peran dalam mengkonstruksi tentang tumbuhnya radikalisme di lembaga pendidikan Islam, yaitu pesantren ini (Andari et al., 2012). Pada perkembangannya, konstruksi berita media massa sering kali dicurigai sebagai produk realitas simbolik di media (second hand reality) yang seluruh isi media tiada lain adalah realitas yang telah dikonstruksikan (constructed reality) dalam bentuk wacana yang bermakna sehingga dapat melahirkan realitas yang bukan sebenarnya (Hamad, 2004; Ibrahim, 2011).

Fenomena kekuatan media dalam mengonstruksikan realitas menyangkut dua hal utama, yaitu: pertama, bahwa media internet mengambil porsi dan peranan yang sangat besar dalam memberikan informasi kepada publik, terutama kaum muda akan ideologi radikal; kedua, media massa memegang peran kunci dalam menangkal dan memberikan informasi ke publik terhadap isu-isu radikalisme sehingga masyarakat dapat melakukan tindakan pencegahan berkembangnya gerakan-gerakan ekstrimis dimulai dari lingkungannya sendiri (Ghifari, 2017).

Realitas empiris mengenai pondok pesantren yang dituding radikal sebagaimana diberitakan Jawa Pos.com, Kompas.com, dan Republika.co.id tidak seperti yang dituduhkan selama ini. Kementerian Agama Republik Indonesia yang melakukan penelitian terhadap 16 pondok pesantren yang diindikasi radikalteror oleh pihak BNPT, hanya mendapatkan 2 (dua) pesantren yang dinilai dapat memenuhi unsur radikalisme (Prihatin, 2019; Raharjo \& Sari, 2019; Ramadhan, 2019).

Bendasarkan pada kenyataan tersebut, konstruksi realitas semu isu terorismeradikalisme terhadap pondok pesantren di Indonesia yang diberitakan Jawa Pos.com, Kompas.com, dan Republika.co.id layak diteliti secara kritis. Fokus pertanyaannya adalah bagaimana konstruksi realitas ketiga media siber tersebut dalam memberitakan isu terorisme-radikalisme terhadap pondok pesantren di Indonesia?
Penentuan objek penelitian didasari oleh reputasi dan kredibilitas ketiga media di Indonesia. Selain itu, pertimbangan ilmiah yang dikritisi penulis dalam penelitian ini adalah tarik menarik wacana isu terorisme-radikalisme yang mengarahkan pada stigmatisasi dengan institusi pendidikan Islam pesantren.

Fenomena ini juga dikritisi dengan menawarkan kurikulum pesantren moderat untuk para santri dalam menghadapi radikalisme yang berkembang melalui berbagai sarana komunikasi, salah satunya melalui jagat maya (cyber media) karena BNPT mengungkapkan bahwa pesantren belum steril dari radikalisme (Ardiansyah, 2019). Isu radikalisme ini yang memantik reaksi berbagai perguruan tinggi di Indonesia dalam melakukan perlawanan terhadap radikalisme di dunia pendidikan (Waziz, 2017).

\section{METODE PENELITIAN}

Kajian ini menggunakan pendekatan kualitatif-kritis yang menyatakan bahwa penelitian kualitatif bersifat interpretatif (menggunakan banyak penafsiran) (Bajari, 2015). Sifat realita yang terbangun secara sosial, hubungan erat antara peneliti dengan subyek yang diteliti, dan tekanan situasi yang membentuk penyelidikan (Denzin \& Lincoln, 2009). Pendekatan kritis menekankan pada tanggung jawab peneliti untuk mengubah ketidakadilan dalam kondisi status quo (West \& Turner, 2012). Ada beberapa alasan yang dikemukakan peneliti.

Pertama, pendapat Littlejohn, Foss dan Thomas yang menyatakan bahwa pandangan kritis mempunyai fokus perhatian pada: a) dominasi dan represi yang diakibatkan ketidakseimbangan power dalam masyarakat, termasuk dominasi, represi ideologi dan kepercayaan; b) upaya mempromosikan emansipasi, kebebasan, dan persamaan dengan menggali kondisi-kondisi sosial yang memarginalkan pihak-pihak tertentu; c) upaya memberikan solusi melalui sinergi teoritis dan praktis agar terwujud perubahan sosial (Krisyantono, 2015).

Kedua, peneliti memilih analisis wacana kritis (AWK) atau Critical Discourse Analysis (CDA) dalam menganalisis berita tentang isu terorisme-radikalisme terhadap pondok pesantren di Indonesia. Salah satu tujuan 
penelitian AWK/ CDA adalah memperlihatkan ketimpangan-ketimpangan dalam teks, menyingkap makna-makna atau kepentingankepentingan yang terselubung dan sebagainya (Haryatmoko, 2016). Teun A. van Dijk, Fairclough, dan Wodak menegaskan lima karakteristik penting AWK, yaitu tindakan, konteks, historis, kekuasaan, dan ideologi (Eriyanto, 2003). AWK model Norman Fairclough dipilih dengan menggunakan tiga dimensi penting, yakni teks, praktik wacana, dan praktik sosiokultural (Fairclough, 1989, 1995, 2010).

AWK model Fairclough memiliki tiga langkah yang saling mendukung, sistematis, logis, dan relevan. Pertama, teks dianalisis secara linguistik; dengan melihat kosa kata, semantik, dan tata kalimat. Kedua, discourse practice merupakan dimensi yang berhubungan dengan proses produksi dan konsumsi naskah. Ketiga, socioculutral practice adalah dimensi yang berhubungan dengan konteks di luar naskah (Badara, 2012; Darma, 2014).

Aplikasi dari analisis Fairclough terfokus tiga langkah. Pertama, tahap deskripsi. Teks berita media siber Jawa Pos, Kompas, dan Republika edisi online 1 Januari-30 Desember 2016 dipilih untuk diidentifikasi wacananya dibalik teks. Keseluruhan narasi teks berita diposisikan tidak netral, tetapi dicurigai memiliki beragam kepentingan. Melalui analisis bahasa kritis (critical linguistic), teks dapat mengungkapkan identitas, representasi, relasi, dan intertektualitas berita.

Kedua, tahap interpretasi. Dalam praktik wacana, peneliti mewancarai tim redaksi untuk mengungkapkan data mengenai proses produksi berita yang terkait. Peneliti juga membandingkan dengan edisi cetak, karena Jawa Pos, Kompas, dan Republika termasuk dalam kelompok media cetak yang memiliki kredibilitas tinggi serta jangkauan luas sebagai massa nasional (Adji, 2017). Ketiga, tahap eksplanasi. Praktik sosiokultural memfokuskan analisis situasional, institusional, dan sosial.

Sumber data dokumentasi sejumlah 18 berita online bertema "isu terorisme-radikalisme terhadap pondok pesantren”, yakni 6 berita Jawa Pos.com, 5 berita Kompas.com, dan 7 berita Republika.co.id untuk mengungkapkan praktik wacana teks berita. Hal ini sejalan dengan pandangan Jorgensen \& Philips (2010) bahwa wacana mempunyai tiga fungsi, yakni fungsi
Tabel 1 Berita Media Siber yang Dianalisis

\begin{tabular}{|c|c|c|c|}
\hline $\begin{array}{c}\text { Insitus i } \\
\text { Media }\end{array}$ & $\begin{array}{c}\text { Ju m l a h } \\
\text { Berita }\end{array}$ & $\begin{array}{c}\text { A l a mat } \\
\text { Web }\end{array}$ & Diakses \\
\hline Jawa Pos & 6 judul & $\begin{array}{l}\text { www. } \\
\text { jawapos. } \\
\text { com }\end{array}$ & $\begin{array}{l}2016- \\
2019\end{array}$ \\
\hline Kompas & 5 judul & $\begin{array}{l}\text { Www. } \\
\text { kompas. } \\
\text { com }\end{array}$ & $\begin{array}{l}2016- \\
2019\end{array}$ \\
\hline Republika & 7 judul & $\begin{array}{l}\text { www. } \\
\text { republika. } \\
\text { co.id }\end{array}$ & $\begin{array}{l}2016- \\
2019\end{array}$ \\
\hline
\end{tabular}

Sumber: Diolah peneliti, 2019

identitas, fungsi "hubungan" atau relasional, dan fungsi "ideasional" (Jorgensen \& Phillips, 2010).

Penggalian data melalui wawancara dilakukan sejak Maret 2017 hingga Desember 2017 kepada pihak redaksi media, diantaranya Miftakhul Fahamsyah (Jawa Pos.com), Amir Sodikin, Ahmad Winarno (Kompas.com), dan Maman Sudiaman, Jaka Sadewo (Republika. co.id). Wawancara dilakukan di media Kompas. com Jl. Palmerah No. 22-28 Jakarta, di redaksi Jawa Pos.com J1. A. Yani No. 88 Surabaya Jawa Timur, dan kantor Republika Online Jl Warung Buncit No. 37 Jakarta. dengan fokus pada analisis teks, praktik wacana media, dan praktik sosiokultural.

Wawancara mendalam dengan informan pesantren, diantaranya $\mathrm{KH}$ Luqman Haris Dimyati (Koordinator Nasional Gerakan Ayo Mondok/ Katib Syuriah PBNU) di Pacitan Jawa Timur, dan Pengasuh Pondok Pesantren Manarul Quran Lumajang Dr. KH. Abdul Wadud Nafis, Lc (Gus Wadud). Sebagai pendukung studi literatur, peneliti literatur seperti disertasi, jurnal penelitian, dan artikel ilmiah yang sejenis dan relevan dengan fokus penelitian (Bajari, 2015).

\section{HASIL DAN PEMBAHASAN}

Realitas semu isu terorisme-radikalisme terhadap pondok pesantren di Indonesia diperoleh berdasarkan analisis hasil penelitian dan pembahasan kritis melalui tahapan deskripsi 
teks, interpretasi praktik wacana, dan eksplanasi praktik sosiokultural yang dikonstruksi Jawa Pos.com, Kompas.com, dan Republika.co.id yang dijelaskan sebagai berikut.

Pertama, berdasarkan analisis deskripsi teks dapat diungkapkan bahwa keseluruhan narasi berita yang dikonstruksikan oleh Jawa Pos.com, Kompas.com, dan Republika.co.id memiliki karakteristik yang berbeda. Ketiga media siber memiliki pemilihan dan pemilahan bahasa jurnalistik yang tidak bisa dilepaskan dari arah dan tujuan kepentingan ideologi media siber.

Narasi redaksi Jawa Pos.com terkait dengan isu terorisme-radikalisme terhadap pondok pesantren menegaskan bahwa wacana kepentingan elit dalam realitas teks media sangat dominan. Kosa kata, kalimat, dan istilah yang digunakan dalam mendeskripsikan realitas isu dengan bahasa jurnalistik yang lugas, ringkas, dan langsung kepada topik yang diungkapkan. Hubungan antara kalimatnya saling mendukung sehingga memperkuat isu yang diangkat sebagai persoalan yang penting dinarasikan.

Wacana isu terorisme-radikalisme terhadap pondok pesantren digambarkan sebagai sesuatu yang serius oleh kalangan elit, meskipun ditolak atau dibantah oleh sebagian pihak pondok pesantren. Hal ini merepresentasikan aspek kemenarikan Jawa Pos.com terhadap nilai berita kontroversial sebagai realitas yang layak dijual ke pasar. Menurut redaktur Jawa Pos. com Miftakhul Fahamsyah, unsur news value kontroversial merupakan salah satu kekuatan berita di Jawa Pos yang dapat menarik perhatian khalayak.

"Unsur kontroversi memang bagian dari news value, karena dapat mengundang rasa penasaran masyarakat. Dari sisi fakta, isu radikalisme dan pesantren layak diberitakan media. Karena selama ini, pesantren kan ramah. Tetapi, kok ada yang menyampaikan atau menuding radikal seperti itu. Tteapi, Jawa Pos juga mengkonfirmasi pesantren yang menolak isu tersebut agar beritanya imbang".

Struktur teks yang diberitakan, dari sisi sumber informan, dikuasai oleh kelompok dominan (elit), yakni wakil ketua MPR RI, kepala BNPT, ketua Komisi VIII, pimpinan Pondok Pesantren Nurul Bayan NTB (ketua MUI Lombok), ketua Yayasan Ponpes
Minhajurrosyidin Jakarta, dan ketua PBNU. Dominasi pernyataan dari kelompok elit menunjukkan bahwa wacana yang layak ditampilkan oleh Jawa Pos.com adalah perspektif elit dan menunjukkan identitas kelompok dominan yang menguasai medan wacana isu.

Wacana pondok pesantren yang terindikasi radikal tidak mendapatkan ruang yang setara sehingga posisi kelompok pesantren ini menjadi terpinggirkan dalam wacana teks. Relasi media dengan elit mendapatkan ruang yang luas, sedangkan relasi dengan kelompok marginal cukup lemah. Sebagaimana diketahui, struktur teks menjadi unsur penting dalam membangun wacana publik karena realitas berita yang ditampilkan adalah bersumber pada partisipan publik yang dipilih dan dikonstruksikan.

Media Kompas.com mengonstruksikan realitas dengan bahasa jurnalistik online yang menolak pengaitan isu terorismeradikalisme dengan pondok pesantren. Baik kosa kata, kalimat, dan istilah yang dipilih menyatakan menolak hubungan pesantren dengan terorisme-radikalisme, meskipun Kompas.com menarasikan adanya pesantren yang terindikasi radikal. Pada sisi yang lain, Kompas.com menggunakan metafora keblinger untuk menekankan adanya pondok pesantren yang berpotensi terjerumus kepada pemahaman radikal. Hal ini merepresentasikan adanya karakteristik pesantren yang berhaluan moderat dengan pesantren yang berpaham radikal atau kekerasan.

Media Kompas.com menarasikan para elit kekuasaan dalam struktur teks berita, mulai wakil MPR RI, presiden Joko Widodo, ketua Majelis Ulama Indonesia (MUI), kepala BNPT, Wapres Jusuf Kalla, anggota Komisi VII DPR RI, ketua Komisi Dakwah MUI, Guru Besar UIN Syariaf Hidayatullah, dan pengasuh Pondok Pesantren Tebu Ireng sebagai partisipan publik yang dikonstruksikan untuk menyikapi isu terorisme-radikalisme terhadap pesantren di Indonesia. Pemilihan dan pemilahan partisipan publik dari kelompok elit menegaskan bahwa wacana elit yang dinilai layak oleh Kompas. com untuk menggambarkan realitas yang diinginkan oleh media. Karena teks berita bersifat tidak netral, unsur keberpihakan atau dukungan kepada partisipan publik (sumber) berita mengindikasikan relasi kuasa yang kuat antara institusi media Kompas dengan para elit 
yang ditampilkan.

Dominasi ruang publik yang dipenuhi narasi teks elit dikonstruksikan melalui ungkapanungkapan yang saling mendukung antara kalimat dalam satu berita yang ditampilkan. Sedangkan gambaran pro kontra tentang isu terorisme-radikalisme dikonstruksikan pada bagian berita secara terpisah. Media Kompas. com memberikan ruang seluas-luasnya bagi kalangan elit untuk mewacanakan isu dan ketika isu ini mendapatkan tanggapan elit lainnya, maka akan dikonstruksikan dalam edisi yang berbeda. Tidak adanya penempatan elit yang berwacana dalam satu berita menunjukkan kuasa media untuk menampilkan realitas berdasarkan kepentingan media.

Narasi teks berita tentang isu terorismeradikalisme terhadap pondok pesantren merepresentasikan relasi kuasa elit melalui identifikasi realitas yang dikonstruksikan oleh redaksi Kompas.com. Keseluruhan teks menceritakan wacana kelompok penguasa karena dominasi partisipan publik dari kalangan elit. Kompas.com tidak menempatkan partisipan publik dari kalangan pesantren yang terindikasi mengajarkan paham radikalisme-terorisme sebagai sumber berita sehingga posisinya semakin termarginalisasi dalam pertarungan wacana di media.

Menurut Managing Editor Kompas.com Amir Sodikin, pemilihan sumber informan dalam berita melalui pertimbangan ketat redaksi, yakni kredibilitas sumber berita dari pihak yang berkompeten dalam menjelaskan peristiwa yang dimaksudkan. Disamping itu, pihaknya berhati-hati dengan isu yang berkembang, termasuk isu terorisme-radikalisme terhadap pondok pesantren.

"Karena yang menyampaikan pihak BNPT sebagai institusi pemerintah yang bertanggungjawab, kami beritakan. Tetapi,

Kompas.com tidak menyebutkan satu persatu nama pesantren tersebut. Isunya kami lihat sesuai dengan perkembangan audience, kalau menarik akan dilanjutkan".

Tidak diberikannya ruang berwacana bagi pesantren yang diindikasi radikal oleh BNPT menjadikan makna teks berita Kompas.com adalah wacana kuasa elit dan media. Dalam hal ini, relasi kuasa media dengan elit menjadi sangat dominan dibandingkan dengan pesantren yang dituding radikali-teror.
Keseluruhan narasi berita yang dikonstruksikan oleh Republika.co.id terkait dengan isu terorisme-radikalisme terhadap pondok pesantren menegaskan bahwa kepentingan elit dalam realitas media cukup dominan. Pemilihan kosa kata, kalimat dan istilah yang digunakan menggambarkan bahwa realitas isu diwacanakan oleh elit dengan kalimat yang saling mendukung.

Media Republika.co.id mengungkapkan penolakan pesantren menjadi persemaian terorisme-radikalisme dan pada saat yang sama mengakui adanya 19 pondok pesantren yang terindikasi mengusung paham kekerasan. Republika online ingin merepresenstasikan dirinya sebagai media yang menampilkan fakta apa adanya mengenai identitas pondok pesantren, baik yang moderat maupun yang berpaham keras.

Struktur teks yang ditunjukkan melalui partisipan berita Republika.co.id didominasi oleh kekuatan elit, diantaranya kepala BNPT, Wakil Presiden, Menkopulhukam, Komisi VIII DPR RI, Direktur PSKTTI-UI, Sekjen MIUMI, dan Pimpinan Pondok Pesantren Modern Gontor. Hal ini menunjukkan kontestasi para elit dalam berebut wacana isu.

Keseluruhan berita yang dikonstruksikan media dengan mendominasikan elit menandakan media cukup hegemonik di dalam menyuguhkan realitas semu kepada khalayak. Relasi dengan elit begitu penting dan dominan sehingga memperkuat asumsi bahwa realitas elit yang menguasai isu, bukan sebagian kalangan pondok pesantren yang dituding teror-radikal.

Narasi elit dalam ruang publik media siber merupakan bentuk kuasa media untuk menghadirkan realitas subjektifpada satu sisi dan membangun relasi kuasa dengan elit pada dimensi yang lain. Praktik narasi teks dalam konteks paradigma kritis jelas mengungkapkan bahwa makna-makna yang ditampilkan oleh media adalah makna realitas yang dipenuhi dengan kekuasaan media dan elit yang ditampilkan.

Citra kuat yang muncul adalah konflik wacana elit, bukan realitas sebenarnya mengenai kebenaran isu terorisme-radikalisme terhadap pesantren. Realitas semu ini didukung dengan kenyataan bahwa sepanjang narasi teks tidak ditemukan berita yang mengungkapkan penindakan, misalnya pemberitaan Republika Online pembinaan hingga penutupan terhadap 
pondok pesantren yang dilabeli mengusung paham terorisme-radikalisme.

Kedua, interpretasi terhadap praktik wacana media terhadap tiga media yang diteliti menunjukkan konstruksi realitas semu isu terorisme-radikalisme terhadap pesantren di Indonesia dengan beragam interpretasi. Relasi kuasa antara media dan kekuatan elit (pemerintah) terjadi tarik menarik. Fenomena ini memperkuat secara historis, hubungan antara kedua belah pihak (pemerintah dan media) diwarnai relasi kuasa yang tidak seimbang (Loisa et al., 2019).

Praktik wacana Jawa Pos.com tentang realitas isu terorisme-radikalisme terhadap pondok pesantren menampilkan kuasa media dalam memproduksi teks dengan kepentingan pasar media. Hal ini bisa dianalisis kritis berdasarkan pertimbangan redaksional ketika memilih realitas dan kepada siapa peristiwa dalam teks itu ditujukan. Proses produksi Jawa Pos.com yang menyandarkan pada news value (nilai berita) sebagai syarat kelayakan sebuah peristiwa diberitakan menunjukkan bahwa berita yang menarik adalah yang diminati "pasar" pembaca Jawa Pos.com. Hanya peristiwa yang memenuhi kriteria "subjektifredaksi" Jawa Pos, seperti unsur baru, unik, dramatik, proximity, aktual, magnitude, tokoh, kontroversi, eksklusif, dan mission yang dipandang layak untuk diproduksi oleh redaksi karena unsurunsur news value itu sejalan dengan perspektif kemenarikan konsumen dalam mengakses berita.

Peristiwa isu terorisme-radikalisme terhadap pondok pesantren dikonstruksikan secara jelas, baik yang dituding radikal-teror maupun pihak pesantren yang membantah tuduhan. Dalam hal ini, realitas isu memiliki unsur kemenarikan dari sisi news value, termasuk ketika dikaitkan dengan pondok pesantren yang dipandang sebagai konsumen media.

Berita tentang isu terorisme-radikalisme terhadap pondok pesantren diproduksi tidak sampai tuntas dan berhenti pada pertarungan wacana elit di media. Pembaca (audience) Jawa Pos online tidak menemukan berita tindak lanjut yang konkret mengenai penindakan terhadap 19 pondok pesantren diindikasikan BNPT menyebarkan radikalisme-terorisme.

Narasi teks yang didominasi oleh elit dalam mewacanakan isu terorisme-radikalisme terhadap pesantren diproduksi oleh tim redaksi Kompas.com dengan mempertimbangkan aspek nilai berita (news value) yang disebutnya sebagai jurnalisme makna. Keseluruhan konstruksi realitas teks berita ditentukan kebijakan redaksi media yang memandang peristiwa tentang isu ini penting untuk ditampilkan sesuai dengan makna subjektifredaksi. Produksi berita dipandang redaksi layak karena elit yang ditampilkan merupakan representasi realitas masyarakat yang berkepentingan dengan isu.

Produksi teks yang disusun oleh tim redaksi Kompas.com menunjukkan bahwa relasi kuasa media dengan elit cukup kuat. Jurnalisme makna yang menjadi identitas Kompas.com adalah banjir informasi memicu kecemasan baru; jurnalisme tak sekadar memaparkan kejadian; tugas jurnalisme memberi interpretasi; tantangannya adalah mencari makna; objektivitas jurnalisme yang subyektif; kembangkan rasionalitas tetapi harus tetap sensitif; perlunya modal sosial dan modal intelektual; tak sekadar berwacana tetapi juga memberi solusi; wacana tak hanya mencerdaskan, tetapi juga mencerahkan; hati-hati jebakan todologi; sosok wartawan apolonisian; dan memaknai kebebasan pers.

Penempatan elit sebagai partisipan publik dalam wacana isu ini memosisikan Kompas. com cenderung memihak kepada wacana adanya pesantren yang terindikasi mengusung radikalisme-terorisme. Hal ini sejalan dengan jurnalisme makna yang menegaskan bahwa tugas jurnalisme memberi interpretasi dan objektivitas jurnalisme yang subjektif menunjukkan kuasa media siber Kompas.com dalam memproduksi berita tentang isu ini.

Kuasa media tergambarkan dalam produksi wacana elit sebagai bentuk jurnalisme makna Kompas.com yang berkaitan dengan poin "tak sekadar berwacana tetapi juga memberi solusi; dan wacana tak hanya mencerdaskan, tetapi juga mencerahkan" diarahkan untuk membentuk kesadaran publik bahwa sebagian pondok pesantren di Indonesia terindikasikan atau dicurigai mengajarkan radikalisme dan terorisme sehingga harus diwaspadai khalayak.

Praktik wacana yang dikonstruksikan Republika.co.id dalam membangun isu terorisme-radikalisme terhadap pesantren di Indonesia didasari oleh pandangan redaksi yang melihat realitas umat Islam sebagai peristiwa yang menarik untuk diberitakan. 
Kehidupan ruang redaksi yang melihat Islam dan umat Islam sebagai fokus yang secara subjektif menarik oleh redaksi, maka isu ini sebagai representasi kepentingan umat Islam di Indonesia mendapatkan prioritas untuk diwacanakan. Produksi tentang isu terorismeradikalisme atas lembaga pendidikan Islam pondok pesantren berkaitan dengan kepentingan Republika terhadap pasar umat Islam.

Media Republika Online mendudukkan elit pemerintah (BNPT) sebagai realitas yang penting ditampilkan dalam menetapkan 19 pondok pesantren yang diduga menyebarkan terorisme-radikalisme. Produksi berita berikutnya adalah respons elit (DPR RI, MUI, Ponpes yang dituding) yang mempertanyakan penetapan 19 pondok pesantren sebagai sikap Republika dalam menyeimbangkan realitas. Hal ini menunjukkan media Republika memiliki kuasa absolut dalam memproduksi isu dan mengarahkan kepada kepentingan umat Islam secara keseluruhan.

Pada satu sisi, produksi berita Republika Online dimaksudkan untuk menampilkan kepentingan elit BNPT sebagai pihak yang diberikan kewenangan mengidentifikasikan penyebaran paham teror dan radikal di tengah-tengah masyarakat. Pada dimensi yang lain, media Republika Online dituntut harus melakukan pembelaan kepada umat Islam melalui penyeimbangan wacana yang dikonstruksikan di media siber. Dalam konteks ini, Republika menampilkan angle (sudut pandang lain) berita yang memberikan ruang penolakan sejumlah pesantren yang dituding atau terindikasi mengusung ide terorismeradikalisme.

Berdasarkan analisis terhadap berita, pertarungan wacana isu ini tidak tuntas. Produk berita Republika tidak menarasikan perkembangan atau tindak lanjut dari penetapan pesantren yang dicap radikal dan teror, baik yang berkaitan pembinaan maupun sanksi yang diberikan kepada ponpes yang dituding mengajarkan "kekerasan".

Pada bagian lain, yakni di kolom Khazanah menampilkan bantahan dari ponpes yang dituding radikal, diantaranya Al Mukmin Ngruki. Strategi ini menjadikan Republika.co.id memiliki pasar konsumen muslim yang dapat terakomodasi melalui konstruksi kelompok marginal pesantren yang diberikan ruang untuk diberitakan. Redaktur pelaksana Republika
Online Mamang Sudiaman menjelaskan sebagai berikut.

"Keberimbangan menjadi penting untuk ditampilkan. Hal ini mengingat, peristiwa itu bersifat indikasimenyebarkan terorismeradikalisme. Ketika ada pemberitaan yang menyebutkan nama pesantren, maka pesantren yang menolak dituding juga harus ditampilkan. Masyarakat muslim sebagai sasaran utama pembaca Republika akan melakukan penilaian".

Ketiga, eksplanasi praktik sosiokultural terhadap ketiga media siber mengungkapkan realitas semu isu terorisme-radikalisme terhadap pondok pesantren di Indonesia dengan beragam narasi. Dalam eksplanasi, peneliti mengungkapkan situasional isu yang dipilih media, sikap institusi media, dan perspektif masyarakat pesantren yang mencermati isu ini sebagai bagian dari realitas.

Institusi Jawa Pos.com sebagai media berideologi Pasar-Ekonomi menempatkan isu ini sebagai realitas pertarungan elit dan kelompok masyarakat lain. Kelompok elit BNPT yang berebut wacana isu diposisikan sebagai partisipan publik yang dominan sehingga diletakkan sebagai pembentuk wacana utama. Berikutnya, kekuatan elit lain, seperti kekuatan politisi (DPR RI) didudukkan sebagai kelompok penyeimbang yang mengkritisi tuduhan isu. Kelompok pesantren yang netral (tidak disebut radikal-teror oleh BNPT) ditampilkan sebagai wacana pembanding dalam pemberitaan prokontra berikutnya bersama dengan elit PBNU.

Posisi kelompok marginal, yakni sebagian pesantren yang dituding radikal dan teror diberikan ruang luas untuk membantah tudingan BNPT. Hal ini dipandang redaksi sudah mewakili kredibilitas berita, meskipun kebijakan redaksi seperti itu menunjukkan kuatnya relasi kuasa media Jawa Pos.com dengan elit dan meminggirkan kelompok marginal pesantren. Dengan menyebutkan partisipan publik pesantren yang diwacanakan marginal, perusahaan Jawa Pos.com tetap tidak kehilangan pasar pembacanya karena mengakomodasi kepentingan kelompok masyarakat pondok pesantren yang dipinggirkan.

Pandangan Jawa Pos terhadap isu terorisme-radikalisme secara umum menarik pasar media. Media Jawa Pos menempatkan realitas aksi teror dan radikal sebagai komoditas 
yang mampu menyedot perhatian khalayak (pembaca/ audiens) Jawa Pos.com. Kepentingan pasar menjadi parameter redaksi dalam mengonstruksikan realitas peristiwa; sepanjang masih diakses secara luas oleh pembaca, maka produksi berita tentang terorisme akan dikomodifikasi menjadi lebih menarik. Dari sisi news value redaksi dipandang tidak menyalahi idealisme media, tetapi dari aspek bisnis media mendapatkan akses yang besar dalam menarik kekuatan pasar khalayak sehingga meningkatkan iklan di laman Jawa Pos.com.

Berdasarkan deskripsi teks dan interpretasi praktik wacana dalam menafsirkan isu ini, media siber Kompas.com mendukung wacana elit tentang 19 pondok pesantren yang berpotensi mengajarkan terorisme-radikalisme. Sebagai media berideologi Kristiani-Humanistik, Kompas.com memandang isu ini dari sisi kemanusiaan bahwa paham kekerasan merusak nilai-nilai kemanusiaan. Media Kompas.com menampilkan kekuatan elit sebagai wacana dominan dalam media siber sehingga menjadi opini khalayak, meskipun diberitakan pro kontra di kalangan elit.

Berdasarkan aspek kemanusiaan, institusi Kompas.com tidak menampilkan pondok pesantren yang diindikasikan mengajarkan terorisme-radikalisme sebagai partisipan publik dan membiarkan kekuatan elit yang berkonstestasi dalam memperebutkan isu di media siber. Politik redaksi Kompas.com yang menekankan jurnalisme makna menilai kekuatan marginal pondok pesantren terindikasi mengajarkan paham kekerasan tidak diletakkan pada pertarungan wacana secara dominan. Pertarungan elit atas wacana isu terorismeradikalisme terhadap pesantren dinilai secara subjektif oleh media Kompas.com sudah terwakili oleh kepentingan kelompokyang merepresentasikan arus kepentingan pasar media Kompas.com.

Kompas.com memaknai isu terorismeradikalisme terhadap pondok pesantren di Indonesia berbeda dengan globalisasi terorisme dan radikalisme yang selama ini diberitakan Kompas.com. Dalam pemberitaan yang menyangkut aksi terorisme, Kompas.com memberikan ruang yang besar dengan fokus bahwa aksi teror merupakan pelanggaran terhadap nilai-nilai kemanusiaan atau kejahatan terhadap hak asasi manusia. Ketika isu terorisme-radikalisme diarahkan pondok pesantren ditampilkan, Kompas.com tidak menempatkannya pada berita yang dimaknai menarik sehingga harus di-blow up dengan beragam angle. Pertarungan wacana elit tentang isu terorisme-radikalisme terhadap pesantren dipandang cukup bermakna dengan pelibatan perwakilan elit, pemerintah (BNPT), wakil rakyat (DPR RI), pondok pesantren (Pengasuh Ponpes Tebu Ireng), intelektual (Guru Besar UIN Syarif Hidayatullah), dan ulama (MUI).

Institusi Republika.co.id sebagai media berideologi Islami-Kebangsaan menempatkan wacana elit sebagai kekuatan yang dominan demi menjaga kepentingan pasar berbasis muslim. Hal ini dikarenakan peristiwa isu terorisme-radikalisme terhadap pesantren dipandang isu sensitif atas ajaran Islam dan umat Islam. Dilihat dari kuantitas berita yang ditampilkan, realitas peristiwa isu ini lebih sedikit dibandingkan dengan konstruksi realitas pondok pesantren yang ramah di media siber Republika.co.id. Hal ini wajar mengingat keberpihakan Republika.co.id kepada pembaca muslim, yang salah satunya didukung oleh kekuatan pondok pesantren.

Redaktur pelaksana Republika Online Mamang Sudiaman menyatakan bahwa Republika sebagaimediaberideologi pergerakan Islam melakukan pembelaan terhadap umat Islam, terutama kalangan pondok pesantren yang dikenal mengajarkan Islam rahmatan lil alamin. Dalam hal realitas isu, media Republika lebih menampilkan elit pondok pesantren modern Gontor sebagai representasi partisipan publik yang memiliki realasi kuasa dengan Republika. Dalam hal ini, pengasuh pesantren Gontor mendapatkan ruang yang luas untuk menolak atau membantah tudingan pesantren terindikasi terorisme-radikalisme.

Media online Republika lebih mendominasikan kalangan intelektual pondok modern sebagai kekuatan wacana di media. Republika.co.id menempatkan pandangan yang menentang pelabelan isu terorisme-radikalisme terhadap pesantren berasal dari alumni pondok modern, bukan pondok salafiyah yang didominasi kalangan NU. Dalam menjaga keberimbangan berita, Republika memperkuat keberimbangan berita, dengan menampilkan pondok pesantren Al Mukmin Ngruki dalam membantah semua tuduhan pihak BNPT. Hal ini semakin mempertegas bahwa isu ini nampak semu dan tidak mudah ditemukan realitasnya 
dalam kehidupan yang sebenarnya.

Kalangan pondok pesantren juga memiliki keberagaman dalam menanggapi isu terorismeradikalismeyang ada di Indonesia. Secara umum, mereka menolak pesantren dikaitkan dengan terorisme-radikalisme karena bertentangan dengan ajaran pesantren yang menyampaikan ajaran Islam rahmatan lil alamin. Secara praktik sosiokultural, penelitian Hidayati (2017) mengungkapkan empat pesantren di Jember yang aktif dalam melakukan penguatan nilainilai moderasi Islam berbasis paham Ahlus Sunnah wal Jama'ah (Aswaja) sekaligus sebagai respon kritis atas maraknya gerakan radikalisme agama di Jember. Diantaranya, Pesantren Nuris Nurul Islam (Nuris) pimpinan K.H. Muhyidin Abdussomad, Pesantren as- Sunniyah Kencong pimpinan K.H. Sadid Jauhari, Pesantren Riyadus Solihin di bawah pengasuhan Gus Fikri, dan Pesantren al-Fatah yang dimotori intelektual pesantren di lingkungan keluarga K.H. Ahmad Shiddiq.

Hasil penelitian ini menyebutkan, respon pondok pesantren yang diteliti beragam, ada yang secara nyata langsung merespon dan membekali santrinya dengan ilmu- ilmu yang berbasis Ahlus Sunnah Wal Jamaah. Ada juga yang tidak terlalu reaktif dengan isu-isu radikalisme agama, dengan tetap berpandangan, bahwa selama Tuhannya Allah dan Nabi-nya Rasulullah Muhammad SAW, dan Al-Qur'an sebagai kitab sucinya, maka mereka masih meyakini bersaudara.

Pesantren Nurul Islam dan As Sunniyah hampir memiliki kesamaan dalam melihat masalah radikalisme agama di Jember. Mereka sama sekali tidak mentolerir masalah radikalisme yang mulai marak berkembang di Jember. Sebab dalam pemahaman mereka, dakwah seharusnya dengan kelembutan dan dengan jalan damai, bukan malah melakukan pengrusakan dan sebagainya.

Pesantren Riyadlus Sholihin dan Al Fatah, lebih terlihat moderat dalam menyikapi hal ini. Dalam pengamatan Titiek Rohanah, kemungkinan sikap moderat itu dipilih dua pesantren ini karena sebagian kiainya terlibat di dalam partai politik. Hal ini pula yang membedakan dengan Nurul Islam dan As Sunniyah. Sebab, kecenderungan yang berpolitik melihat isu dan konteksnya. Jika mereka salah langkah, maka bisa jadi akan menjadi bumerang bagi pengembangan partai politiknya.

Berdasarkan pengamatan, wawancara dan observasi, Titiek menyatakan keempat model pondok pesantren yang berada di wilayah Kabupaten Jember ini memiliki respon yang berbeda dalam menyikapi radikalisme agama. Namun demikian, bukan berarti mereka saling bertentangan antara yang satu dengan yang lainnya, namun mereka memilih jalan dan gayanya sendiri dalam mengembangkan dakwah Islamiyah.

\section{SIMPULAN}

Berdasarkan hasil penelitian dan pembahasan dengan analisis wacana kritis ini dapat disimpulkan bahwa realitas isu terorismeradikalisme terhadap pondok pesantren di Indonesia yang diberitakan media Jawa Pos. com, Kompas.com, dan Republika.co.id merupakan konstruksi realitas semu, narasi tesk tidak tegas, fakta berita kabur, mengandung bias informasi, dan menimbulkan perdebatan.

Pertama, konstruksi realitas teks media, praktik wacana, dan praktik sosiokultural pada media Jawa Pos.com menegaskan bahwa realitas berita isu terorisme-radikalisme terhadap pondok pesantren merupakan realitas semu yang harus dikritisi oleh semua pihak. Kedua, konstruksi realitas teks, praktik wacana, dan praktik sosiokultural pada media siber Kompas.com menunjukkan realitas semu dengan mengakui adanya isu paham kekerasan yang berpotensi terjadi di pesantren, tetapi tidak menerima jika pesantren di Indonesia dikaitkan dengan aksi terorisme-radikalisme. Ketiga, konstruksi realitas teks berita, praktik wacana media, dan praktik sosiokultural terhadap media siber Republika.co.id menunjukkan realitas semua dengan lebih mengedepankan penolakannya terhadap isu ini yang dialamatkan kepada pondok pesantren di Indonesia.

Temuan dalam penelitian mengungkap realitas sebenarnya yang dikonstruksikan oleh ketiga media online tersebut adalah kontestasi kelompok elit dalam memperebutkan wacana isu terorisme-radikalisme terhadap pondok pesantren di Indonesia. Pertarungan kekuasaan elit yang mendominasi ruang publik adalah realitas sesungguhnya yang mengindikasikan keberpihakan ideologi media. Implikasinya, realitas semu yang dikonstruksikan ketiga media siber ini dapat melahirkan kesadaran 
palsu terhadap khalayak (audiens) pengguna media siber.

Kebaruan dari penelitian ini adalah mengungkapkan fakta bahwa berita media massa online yang diteliti tidak merepresentasikan realitas sebenarnya sehingga tidak perlu dijadikan sebagai informasi yang membentuk kesadaran publik. Dalam konteks ini, peneliti menyarankan agar ketiga media siber sebaiknya memberikan keberimbangan dalam penampilan sumber berita di ruang publik (public sphere) agar tidak terjadi dominasi dan hegemoni kekuatan elit terhadap kelompok marginal.

Redaksi media seyogyanya menyuguhkan sumber berita yang berimbang agar publik mendapatkan informasi yang komprehensif. Dalam hal ini, media siber sebaiknya menggunakan perangkat jurnalisme investigasi untuk mengungkap realitas pondok pesantren yang dituding mengusung terorismeradikalisme agar tidak menimbulkan stigma negatif terhadap wajah pondok pesantren di Indonesia.

Atas dasar realitas semu media yang dapat melahirkan kesadaran palsu ini, peneliti menyarankan kepada semua pihak pemerhati media, terutama masyarakat pondok pesantren untuk terus bersikap kritis terhadap setiap pemberitaan media massa, terutama media online agar bisa melakukan kontrol sosial media massa dalam rangka menciptakan kehidupan pers yang sehat, adil, dan bermartabat.

Peneliti mendorong dan mendukung kalangan pondok pesantren untuk membangun jurnalisme pesantren sebagai salah satu bentuk perlawanan dalam menyikapi realitas semu isu terorisme-radikalisme terhadap pondok pesantren di Indonesia yang dikonstruksi media massa mainstream. Tujuannya agar institusi pondok pesantren memiliki ruang media siber yang independen dalam menyampaikan pesan agama Islam rahmatan lil alamin yang selama ini diajarkan dalam kurikulum pesantren yang menolak terorisme-radikalisme

\section{DAFTAR PUSTAKA}

Adji, A. N. (2017). Wanita dalam peringatan hari kartini: kajian pada opini republika, kompas, dan jawa pos. Metalingua, 15(2), 133-143.

Andari, K., Hidayat, D. R., \& Fadilah, E.
(2012). Konstruksi majalah gatra tentang radikalisme di pesantren. E-Jurnal Mahasiswa Universitas Padjadjaran, 1(1), $1-15$.

Ardiansyah, M. Z. (2019). Pesantren hybrid worldview: moderatisasi paradigma penalaran keislaman dan pemenangan kontestasi wacana daring. Jurnal Pendidikan Agama Islam, 7(1), 1-18. https://doi.org/https://doi.org/10.15642/ jpai.2019.7.1.1-18

Badara, A. (2012). Analisis wacana: teori, metode, dan penerapannya pada wacana wedia. Jakarta: Kencana Prenada Media Group.

Bajari, A. (2015). Metode penelitian komunikasi: prosedur, trend dan etika. Bandung: Simbiosa Rekatama Media.

Damanhuri, D. . (2016). Pesantren dan kelas menengah. 6.

Darma, Y. A. (2014). Analisis wacana kritis dalam multiperspektif. Bandung: Reflika Aditama.

Denzin, N. K., \& Lincoln, Y. S (2009). Handbook of qualitative research. Yogyakarta: Pustaka Pelajar.

Dhofier, Z. (2011). Tradisi pesantren: studi tentang pandangan hidup kyai. Jakarta: LP3ES.

Dna. (2016). 19 Pondok pesantren dituding sebarkan paham radikal. http://www. jawapos.com/read/2016/02/02/17138/19pondok-pesantren-dituding-sebarkanpaham-radikal

Eriyanto. (2003). Analisis wacana: pengantar teks media. Yogyakarta: LKiS

Fairclough, N. (1989). Language and power. England. London: Longman Group.

Fairclough, N. (1995). Media discourse. London: Edward Arnold.

Fairclough, N. (2010). Critical discourse analysis the critical study of language. London: Longman Group.

Ghifari, I. . (2017). Radikalisme di internet. Religious. Jurnal Agama Dan Lintas Budaya Uin Sunan Gunung Djati Bandung, 1(2), 127.

Hamad, I. (2004). Konstruksi realitas politik dalam media massa. Jakarta: Granit.

Haryatmoko. (2016). Critical discourse analysis. Jakarta: Raja Grafindo Persada.

Ibrahim, I. S. (2011). Kritik budaya komunikasi: 
budaya, media, dan gaya hidup dalam proses demokratisasi di Indonesia. Yogyakarta: Jalasutra.

Indrawan. (2016). BNPT curigai 19 pondok pesantren dukung terorisme. https:// www.republika.co.id/berita/nasional/ umum/16/02/02/o1 xafr365-bnpt-curigai19-pondok-pesantren-dukung-terorisme

Iskan, D. (2009). Warisan go samola. Bekasi: JePe Press Media Utama.

Jainuri, A. (2016). Radikalisme dan terorisme: akar ideologi dan tuntutan aksi. Malang: Instrans Publishing.

Jauhari, M., \& Muhibbin. (2017). Jurnalisme pesantren dan media cyber: membendung hegemoni media dari bilik pesantren. Fenomena, 16(1), 173-202.

Jorgensen, M. W., \& Phillips, L. J. (2010). Analisis wacana: teori \& metode. Yogyakarta: Pustaka Pelajar.

Kriyantono, R. (2015). Public relations, issue \& crisis management. Jakarta: Kencana Prenada Media Group.

Lestari, P., Ramadhaniyanto, B., \& Wardyaningrum, D. (2018). Pemberitaan di media online untuk pengurangan risiko bencana gunung sinabung. Jurnal Kajian Komunikasi, 6(1), 106-120. https://doi.org/ https://doi.org/10.24198/jkk.v6i1.15168

Loisa, R., Susanto, E. H., Junaidi, A., \& Loekman, F. (2019). Media siber, aparat, dan pemberitaan keberagaman. ASPIKOM, 3(6), 1243-1253. https://doi.org/http:// dx.doi.org/10.24329/aspikom.v3i6.434

Mubarok, I. (2016). Dituding radikal oleh bnpt, ponpes darusy syahadah terus berkembang dan santrinya ribuan orang. http:// www.panjimas.com/news/2016/02/05/ dituding-radikal-oleh-bnpt-ponpesdarusy-syahadah-terus-berkembang-dansantrinya-ribuan-orangponpes-darusysyahadah-sangat-diterima-masyarakat/

Muhibbin, W., \& Choliq, A. (2019). Pesantren dan imperialisme media: perlawanan media pesantren terhadap hegemoni media massa dalam mengonstruksi realitas isu radikalisme-terorisme di Indonesia. Jember: LP2M IAIN Jember

Muhtadi, A. . (2008). Komunikasi politik indonesia: dinamika islam politik pascaorde baru. Bandung: Remaja Rosdakarya.

Mulyana, D. (2008). Komunikasi massa: kontroversi, teori, dan aplikasi. Bandung: Widya Padjadajaran.

Prihatin, I. U. (2019). Kementerian agama temukan dua pesantren berpotensi terpapar radikalisme. https://www.merdeka.com/ peristiwa/kementerian-agama-temukandua-pesantren-berpotensi-terpaparradikalisme.html

Putri, N. E., Hakim, N., \& Yamin, M. (2016). Ecologicall Footprint and Biocapacity Analysis for Flooding Prevention in South Sumatera. Jurnal Mimbar, 32(1), 58-64.

Raharjo, D. B., \& Sari, R. R. N. (2019). Kemenag sebut ada dua pesantren terindikasi radikalisme. https://www.suara.com/ news/2019/11/26/142927/kemenag-sebutada-dua-pesantren-terindikasi-radikalisme

Ramadhan, A. (2019). Menag tak mau buruburu bubarkan pesantren yang terpapar radikalisme. https://nasional.kompas.com/ $\mathrm{read} / 2019 / 11 / 22 / 11040291 / \mathrm{menag}$-takmau-buru-buru-bubarkan-pesantren-yangterpapar-radikalisme

Salam, M. (2005). NU dan transformasi masyarakat madani. Malang: Pustaka Bayan.

Setiyoko, E. (2016). Dituduh mengajarkan radikalisme, ini tanggapan pesantren ngruki. http://www.republika.co.id/berita/ dunia-islam/islam-nusantara/16/02/04/ o 1 zpag 301 -dituduh-mengajarkanradikalisme-ini-tanggapan-pesantrenngruki

Sholeh, B. (2007). Budaya damai komunitas pesantren. Jakarta: LP3ES.

Suharto, B. (2018). Pondok pesantren dan perubahan sosial: studi transformasi kepemimpinan kiai pesantren. Yogyakarta: Pustaka Ilmu.

Suprayoga, I. (2012). Spirit islam тепијu perubahan dan kemajuan. Malang: UIN Maliki Press.

Syuderajat, F. (2017). Ideologi surat kabar dalam pemberitaan terorisme. Communicatus: Jurnal Ilmu Komunikasi. 1(1), 1-12.

Tashandara. (2016a). Bnpt incar 19 pondok pesantren terindikasi radikal. $\mathrm{https://nasional.kompas.com/}$ $\mathrm{read} / 2016 / 02 / 02 / 21383281 / \mathrm{BNPT}$. Incar.19.Pondok.Pesantren.Terindikasi. Radikal

Tashandara, N. (2016b). Bnpt jangan langsung 
tuduh pesantren ajarkan radikalisme. Kompas. http://nasional.kompas.com/ $\mathrm{read} / 2016 / 02 / 04 / 19060731 / B N P T . J a n g a n$. Langsung.Tuduh.Pesantren. Ajarkan. Radikalisme

Wazis, K. (2017). Hegemoni dunia islam melalui globalisasi isu terorisme dan radikalisme. Jurnal Al 'Adalah, 20(1),
167-183. http://ejournal.iain-jember.ac.id/ index.php/aladalah/article/view/740

West, R., \& Turner, L. H. (2012). Pengantar teori komunikasi. Jakarta: Salemba Humanika

Widyaningrum, A. ., \& Dugis, N. . (2018). Terorisme Radikalisme dan Identitas Keindonesiaaan. Jurnal Studi Komunikasi, 2(1), 32-67. https://doi.org/https://dx.doi. org/10.25139/jsk.v2i1.368 